\title{
Optimation of Auxin and Cytokinin on Enhanced Quality and Weight of Coffea liberica Somatic Embryos
}

\author{
Fitria Ardiyani ${ }^{1,2 *}$, Edy Setiti Wida Utami ${ }^{2}$, and Hery Purnobasuki ${ }^{2)}$ \\ ${ }^{1)}$ Indonesian Coffee and Cocoa Research Institute, Jl. PB Sudirman 90, Jember, Indonesia \\ ${ }^{2}$ Department of Biology, Faculty of Science and Technology, Airlangga University, \\ Jl. Dr. Ir. H. Soekarno, Surabaya, Indonesia \\ ${ }^{*}$ Corresponding author: ardiyani.fitria@gmail.com \\ Received: 17 April 2020 / Accepted: 20 September 2020
}

\begin{abstract}
Coffea liberica is a variety of coffee that tolerant to marginal land, especially peatlands. One of propagation methods in $C$. liberica is somatic embryogenesis (SE) which producing large number of true-to-type plant seedlings in a short time. This research aimed at studying the effect of application of plant growth regulator (PGR) on quality and weight of somatic embryo of $C$. liberica. Somatic embryo in development stage was induced by Murashige and Skoog medium containing cytokinin as benzyl amino purin (BAP) and auxin as 2,4-dichlorophenoxyacetic acid (2,4-D). While cotyledonary embryo in germination stage was induced by Murashige and Skoog medium containing cytokinin (BAP) and auxins as 2,4-D, indole acetic acid (IAA) and naphthaleneacetic acid (NAA). The results showed that the application of auxins and cytokinins on development stage affected the formation of embryos, texture of calli, color of calli and embryos, and weight of somatic embryos. It also influenced the shoot and root formation, color and weight of germinating embryos of $C$. liberica at the germinating stage. During the development stage, addition of $1 \mathrm{mg} . \mathrm{L}^{-1} \mathrm{BAP}$ in the absence of 2,4-D in MS medium produced the highest quality of somatic embryo of $C$. liberica. This medium also produced heaviest somatic embryos but with lighter callus. While in germination stage, all medium treatments produced a typical germinating embryo. Coffea liberica germinating embryo grew optimally on MS medium containing $0.5 \mathrm{mg} . \mathrm{L}^{-1} \mathrm{BAP}$ as a single chemical or $0.5 \mathrm{mg} . \mathrm{L}^{-1} \mathrm{BAP}$ in combination with $0.5 \mathrm{mg} . \mathrm{L}^{-1}$ IAA for shooting development. Whereas on rooting development, addition of $0.5 \mathrm{mg} . \mathrm{L}^{-1} \mathrm{NAA}$ on $\mathrm{MS}$ medium produced an optimal germinating embryo. Moreover, germinating embryo of $C$. liberica recorded the highest in terms of dry weight on MS media with addition of $0.5 \mathrm{mg} . \mathrm{L}^{-1}$ BAP. Application of appropriate concentration of auxin and cytokinin is needed to support the formation of somatic embryos and germinating embryos.
\end{abstract}

Keywords: callus, somatic embryo, quality, weight, Coffea liberica

\section{INTRODUCTION}

Coffee is one of the commercial commodities in Indonesia that has great economic value in the global trading. In addition to C. arabica and $C$. canephora, there are two minor species that prominent in the trade of coffee beans and the cultivation, such as C. liberica and
C. dewevrei (Sridevi \& Giridhar, 2014). Coffea liberica var. liberica and C. liberica var. dewevrei are highly resistant to rust infections with good yield, require optimum temperature and light for cultivation (Lopes \& Monaco, 1979). Its level of caffeine is about $1.2 \%$ (Ashihara \& Crozier, 2001). Coffea liberica is cultivated for a special taste, 
superior in agronomic character (simultaneous ripening period of fruit with larger size of seeds), low caffeine content, high adaptability to high salinity environment and peatland area (N'Diaye et al., 2005). Coffea liberica is tolerant to grow on marginal land, especially peatlands which other varieties find it unsuitable. Indonesia and Malaysia are two countries with a large development area for $C$. liberica in addition to Philippines and Vietnam to smaller extent (Wintgens, 2004). Propagation on $C$. liberica uses several methods. True-totype plant propagation is possible only through clonal propagation, which includes macropropagation methods such as grafting and cutting as well as micropropagation (Ahmed et al., 2013). Micropropagation via somatic embryogenesis (SE) also permits the production of true-to-type plant on a large-scale within a short period of time (Etienne et al., 2006).

Somatic embryogenesis is a developmental process where a plant somatic cell can differentiate to a totipotent embryonic cell that has the ability to give rise to embryo under appropriate conditions. This technology is important for woody plants that have a long life cycle and those that difficult to propagate by conventional methods (Isah, 2016). It can produce large numbers of true-to-type plant seedling in a short time (Etienne et al., 2006). Since 2000s, SE has enabled and developed as propagation method for coffee clones. For C. canephora many research have been reported related to the application of this method (Muniswamy et al., 2017). Similarly, the same reports are widely available on somatic embryogenesis of $C$. arabica (Ahmed et al., 2013). Meanwhile, somatic embryogenesis in C. liberica still have a few reference (Ardiyani, 2015). Different to C. arabica and C. canephora, research on somatic embryogenesis of $C$. liberica has not been done much, especially on the application of plant growth regulators in culture medium.

One factor that affecting SE process is plant growth regulator (PGR). PGRs are specific to plant species (Santana-Buzzy et al.,
2007). They must be provided precisely and specifically in the context of type and quantity. Various type of PGRs produce different responses (Aga \& Khillare, 2017). Types of PGRs those frequently used are auxins and cytokinins. The most familiar auxins are 2,4dichlorophenoxyacetic acid (2,4-D), indole acetic acid (IAA) and naphthalenela-cetic acid (NAA), while cytokinins are kinetin, BA and benzyl amino purin (BAP). Auxin is required for proliferation of a proembryogenic mass (PEMs) but inhibits the development of PEMs into somatic embryos (Yang $\&$ Zhang, 2010). Cytokinin promotes plant growth, has antiaging potential, also protective effects for plants. Cytokinins can also enhance nutrition product, involved in cell growth and promoted differentiation. Auxins and cytokinins have a crucial role in regulation of organ regenerations, and the concentration ratio between these hormones are critical for determining specific organogenesis processes. In some plants, using auxins and cytokinis affect growth quality of somatic embryo. The study of Medicago truncatula also confirmed that higher auxin (NAA) level improved embryo quality (Nolan \& Rose, 1998). There are various reports available for micropropagation of citrus varieties through callus formation and regeneration in the pre-sence of 2,4-D and BAP (Ali \& Mirza, 2006). Culture medium containing growth regulators have a correlation with type of callus, somatic embryo multiplication frequency and the time spent exposed (Konan et al., 2010).

Optimal quality performance and weight of somatic embryo influence their potentiality to develop to plantlet. Guan et al. (2016) stated that maturation and quality of somatic embryos are further limiting factors in converting embryos into plants. One of limiting factors that influenced the maturation and quality of somatic embryo is PGR. Therefore, this research discuss about the effect of application of several concentration of auxins and cytokinins to enhance the quality and weight of somatic embryo $C$. liberica. 


\section{MATERIALS AND METHODS}

\section{Preparation explant and media}

This research was done at Tissue Culture Laboratory, Indonesian Coffee and Cocoa Research Institute, from May to December 2019. This research used embryogenic calli of $C$. liberica for development stage, and cotiledonary embryos for germinating stage. These explants were cultured on MurashigeSkoog (MS) medium containing auxin and cytokinin. For cytokinin benzyl amino purin/ BAP was used, while for auxins 2,4,-dichlorophenoxy acetic acid/2,4-D, indole acetic acid/IAA and naphthaleneacetic acid/NAA were used. This medium is also combined with vitamin B5, gelling agent/gelrite and sucrose. For observation, the inverted Olympus SZ51 stereo microscope was used. Tissue culture process is carried out in the laminar air flow (LAF) Esco-ULFA-AHC-601.

\section{Development Stage}

During the development stage, $1 \mathrm{mg}$ of embryogenic calli of $C$. liberica were cultured in medium treatments. Culture preparation on this research used Murashige-Skoog medium, 30 g. $\mathrm{L}^{-1}$ sucrose, vitamin B5 and addition of $1 \mathrm{mg} . \mathrm{L}^{-1}$ BAP combined with $0.5,1,1.5$, $2 \mathrm{mg} . \mathrm{L}^{-1}$ 2,4-D and without addition of 2,4-D (Berthouly \& Michaux-ferriere (1996). Embryogenic calli were cultured in petridish (diameter $50 \mathrm{~mm}$ ). Each treatments applied 30 replications. All treatments medium were solidified with gelrite $3 \mathrm{~g} . \mathrm{L}^{-1}$, and $\mathrm{pH}$ was adjusted to 5.6-5.8. This medium were sterilized by autoclave at $120^{\circ} \mathrm{C}$ for $20 \mathrm{~min}$. These cultures were placed in the dark incubation rooms at $25-28^{\circ} \mathrm{C}$ and $80 \%$ humidity. This cultures were incubated for 12 weeks and sub-cultured in the same medium every 2 weeks. In this stage, observation were done for embryos formed, texture and color of calli as well as embryos. Embryo formed and color of embryo were used to determine embryos quality, so that can be used as an explant during the germination stage. Weight of callus, cotyledonary embryos and total embryos also observed by analytical scales Mettler Toledo Xs205du.

\section{Germination Stage}

In germination stage, the $2 \mathrm{~mm}$ length of cotiledonary embryos were used as explants. Culture medium in germination stage consisted of Murashige-Skoog medium as basic media, vitamin B5, 30 g.L.- sucrose, 4 g.L. $L^{-1}$ gelling agent (gelrite), and addition of PGR, such as $0.5 \mathrm{mg} . \mathrm{L}^{-1} \mathrm{BAP}(1), 0.5 \mathrm{mg} . \mathrm{L}^{-1} \mathrm{IAA}(2)$, $0.5 \mathrm{mg} . \mathrm{L}^{-1} \mathrm{NAA}(3), 0.5 \mathrm{mg} \cdot \mathrm{L}^{-1} \mathrm{BAP}+0.5$ mg. $\mathrm{L}^{-1} \mathrm{NAA}(4)$ and $0.5 \mathrm{mg} \cdot \mathrm{L}^{-1} \mathrm{BAP}+0.5$ mg. $L^{-1}$ IAA (5). The cotyledonary embryos were cultured in petridish $(160 \mathrm{~mm}$ in diameter), and each of treatments were replicated for 10 times. The cotyledonary embryos were placed in the growth room at constant temperature of $25-28^{\circ} \mathrm{C}, 80 \%$ humidity and 8-h dark/16-h light photoperiod for 12 weeks. Quality parameters on the germination stage observed were the formation of shoot and root, and color of germinating embryos. Whilst, size and weight of germinating embryo were also observed in this research. For the dry weight, data were obtained from 5 destructive samples of germinating embryos for each treatments. The dry weight of germinating embryos were obtained from the samples dried at $80^{\circ} \mathrm{C}$.

\section{Data Collection and Analysis}

This research observed somatic embryo quality and weight during the development and germination stages. In the development stage, there were 5 treatments of PGR, namely, $1 \mathrm{mg} . \mathrm{L}^{-1}$ BAP combined with 0.5 , 1, 1.5, 2 mg.L. $\mathrm{L}^{-1}$ 2,4-D and without addition of 2,4-D. Whereas in germination stage, there were also 5 treatments, such as $0.5 \mathrm{mg} . \mathrm{L}^{-1}$ 
BAP, $0.5 \mathrm{mg} . \mathrm{L}^{-1} \mathrm{IAA}, 0.5 \mathrm{mg} . \mathrm{L}^{-1} \mathrm{NAA}, 0.5$ mg. $\mathrm{L}^{-1} \mathrm{BAP}+0.5 \mathrm{mg} \cdot \mathrm{L}^{-1} \mathrm{NAA}$ and $0.5 \mathrm{mg} . \mathrm{L}^{-1}$ BAP $+0.5 \mathrm{mg} \cdot \mathrm{L}^{-1}$ IAA. This assessment on the somatic embryo quality and weight were done qualitatively by determining the formation of callus and embryos, callus and embryo color and texture of callus. Quantitative assessment were done by weighing of callus, cotyledonary embryos and total embryos. Embryos quality was divided into two categories, namely, good quality embryos, that is white cotyledonary embryo, and the yellowish unvigorous embryos. In germination stage, qualitative variable were done through the formation shoot and root and color of germinating embryos. Whilst quantitative assessment were using the size and weight of germinating embryos. This research employed a completely randomized design (CRD) with 5 treatments of combination of auxins and cytokinins in several concentrations during the development stages. Each treatments were replicated for 30 times. For germination stages, it also employed a CRD with 5 treatments and 10 replications. Data were analyzed statistically using SPSS (version 17.0). Analysis of variance was used to test if there any significant difference among the treatments, and followed by Duncan test (0.05). The $\mathrm{P}$ value of $<0.05$ was considered as significant.

\section{RESULTS AND DISCUSSION}

Embryogenic callus of $C$. liberica responded positively to all medium of cultures. It grew and developed into somatic embryos (Figure 1). In this stage, cells on embryogenic callus developed individually become somatic embryos. In somatic embryo-genesis, the addition of PGR stimulated callus to develop and affect the quality of somatic embryos.

\section{Callus on Development Stage}

Embryogenic callus of $C$. liberica in MS medium containing BAP without addition of 2,4-D demonstrated a different quality from embryogenic callus cultured in the medium containing of BAP and 2,4-D (Table 1).
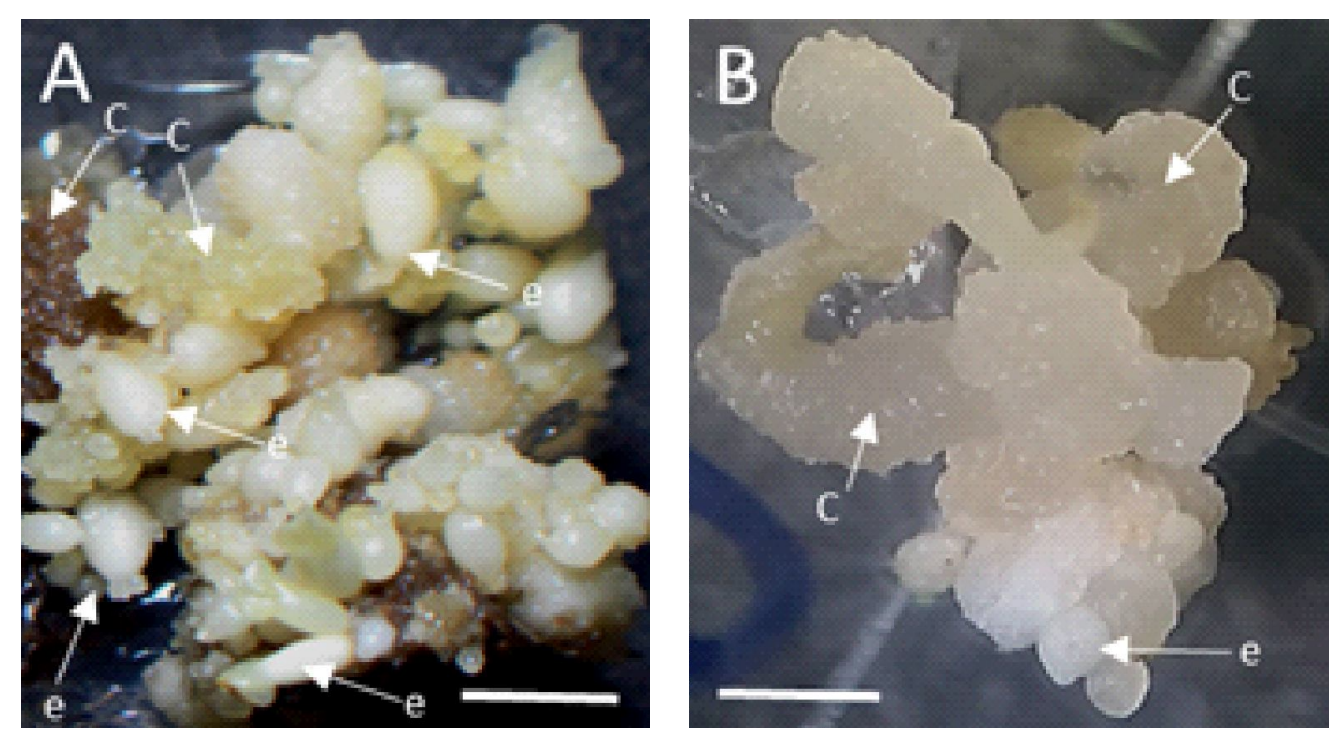

Figure 1. Somatic embryo C. liberica in (A) MS medium with adding $1 \mathrm{mg} \cdot \mathrm{L}^{-1}$ BAP without 2,4-D, (B) MS medium with adding $1 \mathrm{mg} . \mathrm{L}^{-1} \mathrm{BAP}+2 \mathrm{mg} \cdot \mathrm{L}^{-1}$ 2,4-D. e = embryo; c = callus, Bar : $1 \mathrm{~mm}$ 
The results showed that after 12 weeks of culture (W12), callus of C. liberica was formed in all treatments medium. The number of callus on MS medium containing $1 \mathrm{mg} . \mathrm{L}^{-1} \mathrm{BAP}$ individually and callus on MS medium containing $1 \mathrm{mg} . \mathrm{L}^{-1} \mathrm{BAP}$ and 0,5 mg. $L^{-1} 2,4-D$ reduced in $8^{\text {th }}$ weeks after culture, which is not observed for other treatments. MS medium containing $1 \mathrm{mg} . \mathrm{L}^{-1} \mathrm{BAP}$ and 1-1.5 mg. $\mathrm{L}^{-1} 2,4-\mathrm{D}$ produced brown and friable calli. It means the calli still embryogenically and potentially develop into somatic embryo. While on MS medium supplemented with $1 \mathrm{mg} . \mathrm{L}^{-1}$ BAP and $2 \mathrm{mg} . \mathrm{L}^{-1}$ 2,4-D produced brown and compact calli. Likewise, MS medium containing $1 \mathrm{mg} . \mathrm{L}^{-1} \mathrm{BAP}$ without addition of $2.4 \mathrm{D}$, and MS medium containing $1 \mathrm{mg} . \mathrm{L}^{-1} \mathrm{BAP}$ and $0.5 \mathrm{mg} \cdot \mathrm{L}^{-1}$ 2,4-D produced aqueous calli. The formation of compact and aqueous calli showed a decrease in the quality and performance of embryogenic cells. Embryogenic calli were friable, light, glossy, and consisted of separated individuals, while non embryogenic calli were compacted, less friable, and hard clustered structure with dark brown color (Ardiyani, 2015). A 2,4-D is one of the most commonly auxins used in plant tissue culture practices. Auxins are well known for the induction of embryogenesis either as a single chemical or in combination with different hormones. This findings are in accordance with result of Kazmi et al.
(2015), who reported the culture medium with $2.5 \mathrm{mg} . \mathrm{L}^{-1} 2,4-\mathrm{D}$ and $0.5 \mathrm{mg} . \mathrm{L}^{-1}$ BAP in Citrus reticulata blanco L. produced friable and embryogenic callus. In Moringa oleifera, MS medium supplemented with $11.31 \mu \mathrm{M}$ 2,4-D and 2.21 $\mu \mathrm{M}$ BAP transformed embryo explants directly to friable callus on periodically sub-cultured (Devendra et al., 2012). Vondrákov et al. (2011) also confirmed that cytokinins and auxins were suitable for induction of the embryogenic suspensor mass (ESM) from the mother explants. Kaviani (2013) reported that in Camellia sinensis L., the most effective concentration for somatic embryo initiation were obtained from the addition of $1 \mu \mathrm{M}$ of 2,4-D. Generally, auxins promote cell division and root differentiation on tissue culture. Moreover, auxins are also used for inducing cell division, cell elongation, and formation of callus.

\section{Somatic Embryo on Development Stage}

In the development stage, MS medium supplemented with BAP and 2,4-D are also produced somatic embryos. Somatic embryos of $C$. liberica were able to produce from all treatment mediums. Medium of MS containing $1 \mathrm{mg} . \mathrm{L}^{-1} \mathrm{BAP}$ in the absence of 2,4-D produced more somatic embryos than different treatments (Table 2).

Table 1. Quality of embryogenic calli C. liberica on MS medium with BAP and 2,4-D at 0, 4, 6, 8, 10 and 12 weeks after culture

\begin{tabular}{|c|c|c|c|c|c|c|c|c|c|c|c|}
\hline \multirow{2}{*}{ Treatments } & \multicolumn{5}{|c|}{ Callus formed } & \multicolumn{5}{|c|}{ Color of callus } & \multirow{2}{*}{$\begin{array}{l}\text { Texture of } \\
\text { callus W12 }\end{array}$} \\
\hline & W4 & W6 & W8 & $\mathrm{W} 10$ & W12 & W4 & W6 & W8 & W10 & W12 & \\
\hline $\begin{array}{l}1 \mathrm{mg} \cdot \mathrm{L}^{-1} \text { BAP } \\
\text { (without 2,4-D) }\end{array}$ & ++ & + & + & + & + & B & B & PY & PY & PY & aqueous \\
\hline $\begin{array}{l}1 \mathrm{mg} \cdot \mathrm{L}^{-1} \mathrm{BAP}+ \\
0.5 \mathrm{mg} \cdot \mathrm{L}^{-1} 2,4-\mathrm{D}\end{array}$ & ++ & ++ & + & + & + & B & B & PY & PY & PY & aqueous \\
\hline 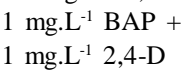 & ++ & ++ & ++ & ++ & ++ & B & B & B & B & B & friable \\
\hline $\begin{array}{l}1 \mathrm{mg} \cdot \mathrm{L}^{-1} \text { BAP + } \\
1.5 \mathrm{mg} \cdot \mathrm{L}^{-1} 2,4-\mathrm{D}\end{array}$ & ++ & ++ & ++ & ++ & ++ & B & B & B & B & B & friable \\
\hline $\begin{array}{l}1 \mathrm{mg} \cdot \mathrm{L}^{-1} \mathrm{BAP}+ \\
2 \mathrm{mg} \cdot \mathrm{L}^{-1} 2,4-\mathrm{D}\end{array}$ & ++ & ++ & ++ & ++ & ++ & B & B & B & B & B & compact \\
\hline
\end{tabular}

Notes: $+=$ few calli, $++=$ profuse calli, $\mathrm{B}=$ brownish color, $\mathrm{PY}=$ pale yellow color. 
Table 2 showed that embryogenic callus on MS medium containing $1 \mathrm{mg} . \mathrm{L}^{-1} \mathrm{BAP}$ in the absence of 2,4-D produced a lot of somatic embryos than MS medium containing BAP and 2,4-D. The quality of somatic embryos were described at the respective developmental stages. During embryogenesis, clear developmental stages were recognized. In 12 weeks after culture somatic embryo in globular, heart, torpedo and cotyledonary stages were formed from all treatment mediums. Whilst, white somatic embryos indicated an initiation of germination (Figure 2A). Whereas yellow somatic embryos showed a bit weaker (Figure 2B). These somatic embryos produced from MS medium containing $1 \mathrm{mg} . \mathrm{L}^{-1} \mathrm{BAP}$ and 1.5-2 mg.L $\mathrm{L}^{-1} 2,4-\mathrm{D}$.

Addition of PGRs in the culture medium affected the formation of somatic embryos C. liberica. This result indicates a reduced or an inhibited development stage during the formation of somatic embryos $C$. liberica. Vondrákov et al. (2011) indicated that development of embryogenic suspensor mass into mature embryos can be induced by transfer it onto medium lacking of auxins and cytokinins. In different samples, such as cucumber and carrot, removal of 2,4-D and decreasing in IAA limit of callus proliferation leading to establishment of pre-globular embryos and development of somatic embryo on the same medium (Ogata et al., 2005).

Addition of BAP in the absence of 2,4-D produced optimal somatic embryos of $C$. liberica formation. In different cases, such as on C. arabica, the highest percentage of somatic embryos development was obtained from MS medium containing $4.0 \mathrm{mg} . \mathrm{L}^{-1} \mathrm{BAP}$ (Ahmed et al., 2013). Nakamura et al. (1992) reported the highest somatic embryos of $C$. arabica obtained from MS medium supplemented with $1.0 \mathrm{mg} . \mathrm{L}^{-1} \mathrm{BAP}$ as the sole PGR. Cytokinins induce cell division and differentiation.

\section{Callus and somatic embryo weight}

Addition of BAP and 2,4-D on C. liberica development medium also affected callus and somatic embryo weight (Table 3). The results

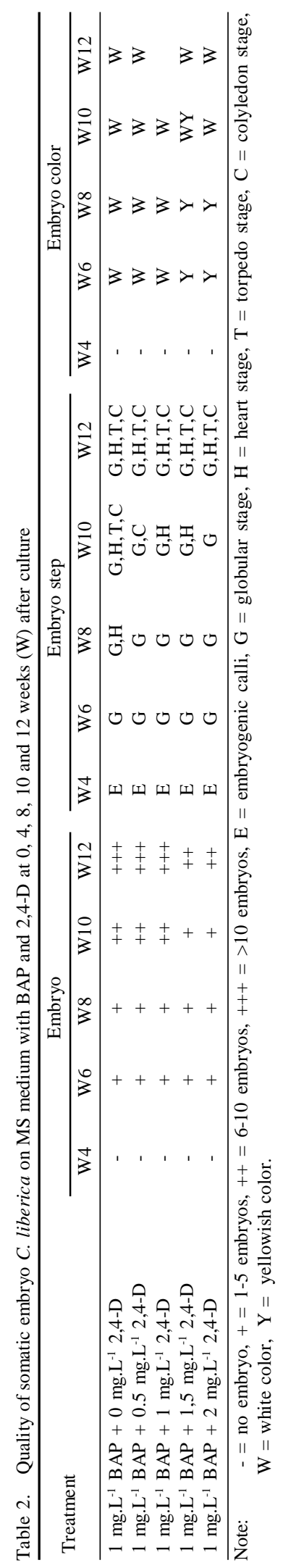




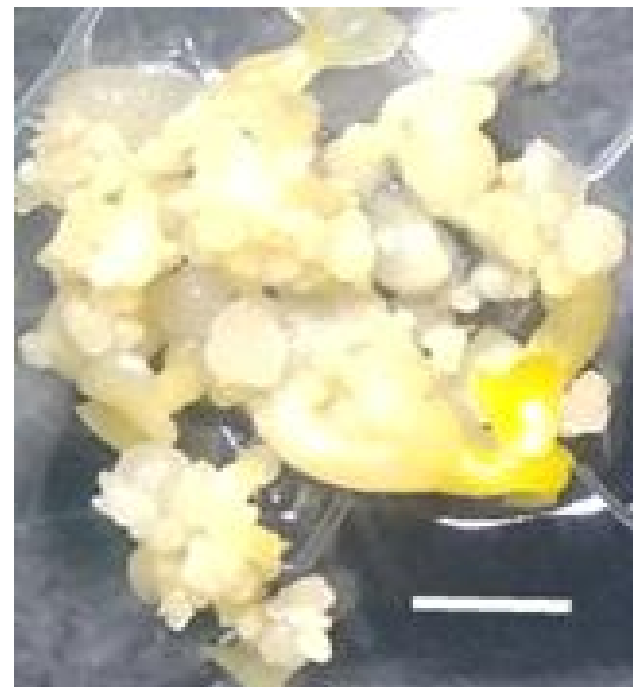

A

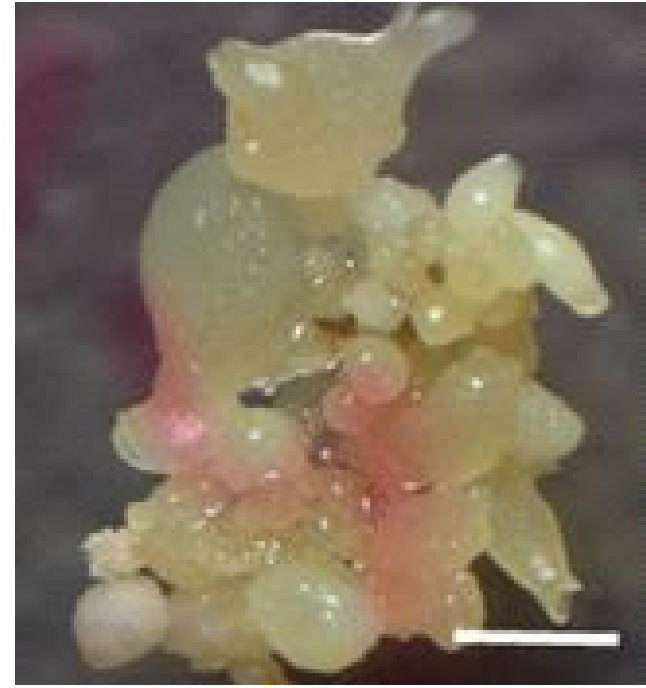

B

Figure 2. Somatic embryo on MS medium with adding BAP without 2,4-D (A), somatic embryo on MS medium with adding BAP and 2,4-D (B) at 12 weeks after culture; Bar : $1 \mathrm{~mm}$

were significantly different among treatment at 12 weeks after culture.

Embryogenic callus on MS medium containing $1 \mathrm{mg} . \mathrm{L}^{-1} \mathrm{BAP}$ without 2,4-D produced heaviest somatic embryos but with lighter calli. These results were significantly different from other treatments. The addition of $1 \mathrm{mg} . \mathrm{L}^{-1}$ BAP and 0.5-2 mg.L $\mathrm{L}^{-1}$ 2,4-D reduced somatic embryos weight, but increased for calli. Nutrient absorption on somatic embryos is better than the same absorption for calli. Additionally, the application of $1 \mathrm{mg} . \mathrm{L}^{-1} \mathrm{BAP}$ in MS medium individually stimulated somatic embryos formation, but conversely inhibit callus formation. Addition of $1 \mathrm{mg} . \mathrm{L}^{-1}$ BAP and 2,4-D also affected the cotyledonary embryos weight. Heavier cotyledonary embryos were resulting in the better growth performance than the lighter embryos. The data in the Table 3 showed that weight of cotyledonary embrio on MS medium containing $1 \mathrm{mg} . \mathrm{L}^{-1}$ of BAP in the absence of 2,4-D obtained significantly different results in compare to other treatments $(51.75 \mathrm{mg})$. However, the development of somatic embryo is more important than callus. Somatic embryos with optimal quality are required during the germination stage. Similar trend was observed, callus induction on auxin containing medium and embryo development on auxin free medium is being used as standard method in a wide range of plant species (Raghavan, 2004).

\section{Germination Stage}

Somatic embryos have been developed on germination medium containing fully Murashige-Skoog medium with addition of auxins and cytokinins. This PGRs were applied as a single chemical or in combination with different hormones. The result of this research showed a different quality of germinating embryo of $C$. liberica in each of treatment (Table 4).

The study reported that all medium treatments produced normal germinating embryos. Roots and shoots have developed and grown up to planlet. Coffea liberica roots emerged at 12 weeks after culture in all medium treatments, whereas the shoot appeared at 4 weeks after culture in MS medium containing $0.5 \mathrm{mg} . \mathrm{L}^{-1}$ BAP. This medium supported for shoot development and produced higher number of shoots than other treatments. 
The results also showed that at $12^{\text {th }}$ weeks after culture, the color of germinating embryo changed from white to greenish. Greenish embryos expressed a high quality and potential embryos to continuously grow up to a plantlet. The color changing on germi nation embryos had been caused by 8-h dark/ 16-h light photoperiod. Cybularz-Urban et al. (2007) stated that in Orchidacae, light intensity has strong energy to affect morphology including the color of germinating embryos. Light energy is absorbed by chlorophyll, a photosynthetic pigment of the plant, and used for photosynthesis processes. Photosynthesis is the process in which light energy is converted into chemical energy. Using the energy of light, carbohydrates such as sugars are synthesized from carbon dioxide and water. This energy is needed for growth of embryo. Therefore, photoperiod affects the development of germinating embryo optimally.

In addition, size of root and shoot C. liberica were also influenced by addition of auxins and cytokinins. Coffea liberica germinating embryos grew optimally on MS medium supplemented with $0.5 \mathrm{mg} . \mathrm{L}^{-1} \mathrm{BAP}$ and $0.5 \mathrm{mg} . \mathrm{L}^{-1} \mathrm{BAP}$ combining with 0.5 mg. $\mathrm{L}^{-1}$ IAA for shooting development. Whereas on rooting development, adding
$0.5 \mathrm{mg} \cdot \mathrm{L}^{-1} \mathrm{NAA}$ in MS medium produced optimal germinating embryo (Table 5).

Addition of auxins and cytokinins on germination medium provided different length of shoot. Culture medium with $0.5 \mathrm{mg} . \mathrm{L}^{-1}$ BAP and $0.5 \mathrm{mg} . \mathrm{L}^{-1} \mathrm{BAP}$ combining with $0.5 \mathrm{mg} . \mathrm{L}^{-1}$ IAA resulted in the longest shoot among the treatments. Supplemented BAP individually or combining with another PGRs increased the length of shoot. It occurred because of division, development and elongation processes of apical meristem. Similar trend was observed in Aquilaria malaccensis culture, $0.5 \mathrm{mg} / \mathrm{L}$ BAP increasing the shoot length (Wardatutthoyyibah et al., 2015). The interaction of auxin and cytokinin affect several processes in plants, such as the initiation and maintenance of plant tissue (Hua Su et al., 2011). According to Fereol et al. (2002), auxins generally inhibit shoot development, whereas the combination of cytokinins and auxins supporting shoot and leaf development. Combination of auxins and cytokinins are also affecting on germinating embryo elongation. The optimal concentrations combination of auxins and cytokinins, stimulate protein synthesis in plant tissue then stimulating cell division and elongation, which affect length of plantlet (Widiastoety, 2014).

Table 3. The effect of BAP and 2,4 D on weight of embryo and callus $C$. liberica from $1 \mathrm{mg}$ callus at $12^{\text {nd }}$ weeks of age

\begin{tabular}{|c|c|c|c|}
\hline Medium culture & Callus weight (mg) & Total weight embryo (mg) & $\begin{array}{l}\text { Weight of embryo } \\
\text { cotyledonary (mg) }\end{array}$ \\
\hline $1 \mathrm{mg} . \mathrm{L}^{-1}$ BAP (without 2,4-D) & $5.50 \pm 0.45^{\mathrm{ab}}$ & $64.491 \pm 2.43 \mathrm{c}$ & $51.76 \pm 2.33^{d}$ \\
\hline $1 \mathrm{mg} \cdot \mathrm{L}^{-1} \mathrm{BAP}+0.5 \mathrm{mg} \cdot \mathrm{L}^{-1} 2,4-\mathrm{D}$ & $5.34 \pm 0.79^{a}$ & $36.224 \pm 1.71 \mathrm{~b}$ & $28.07 \pm 1.55^{\mathrm{c}}$ \\
\hline $1 \mathrm{mg} \cdot \mathrm{L}^{-1} \mathrm{BAP}+1 \mathrm{mg} \cdot \mathrm{L}^{-1} 2,4-\mathrm{D}$ & $7.23 \pm 0.77^{\mathrm{c}}$ & $17.456 \pm 1.01 \mathrm{a}$ & $11.53 \pm 0.99^{\mathrm{a}}$ \\
\hline $1 \mathrm{mg} \cdot \mathrm{L}^{-1} \mathrm{BAP}+1.5 \mathrm{mg} \cdot \mathrm{L}^{-1} 2,4-\mathrm{D}$ & $6.04 \pm 0.70^{b}$ & $17.715 \pm 1.04 \mathrm{a}$ & $12.11 \pm 0.94^{\mathrm{a}}$ \\
\hline $1 \mathrm{mg} \cdot \mathrm{L}^{-1} \mathrm{BAP}+2 \mathrm{mg} \cdot \mathrm{L}^{-1} 2,4-\mathrm{D}$ & $9.14 \pm 0.79^{\mathrm{d}}$ & $18.188 \pm 0.53 \mathrm{a}$ & $13.63 \pm 0.51^{\mathrm{b}}$ \\
\hline
\end{tabular}

Table 4. Morphology of germinating embryo $C$. liberica at $0,4,8$, and 12 weeks (W) after culture

\begin{tabular}{|c|c|c|c|c|c|c|c|c|c|c|c|c|}
\hline \multirow{2}{*}{ Treatments } & \multicolumn{4}{|c|}{ Root in } & \multicolumn{4}{|c|}{ Shoot in } & \multicolumn{4}{|c|}{ Embryos color in } \\
\hline & W0 & W4 & W8 & W12 & W0 & W4 & W8 & W12 & W0 & W4 & W8 & W12 \\
\hline $0.5 \mathrm{mg} / \mathrm{L}^{-1} \mathrm{BAP}$ & - & - & - & + & - & + & + & ++ & $\mathrm{W}$ & $\mathrm{W}$ & $\mathrm{Y}$ & G \\
\hline $0.5 \mathrm{mg} / \mathrm{L}^{-1} \mathrm{IAA}$ & - & - & - & + & - & - & + & + & W & W & $\mathrm{Y}$ & YG \\
\hline $0.5 \mathrm{mg} / \mathrm{L}^{-1} \mathrm{NAA}$ & - & - & - & + & - & - & + & + & W & $\mathrm{W}$ & $\mathrm{Y}$ & $\mathrm{G}$ \\
\hline $0.5 \mathrm{mg} / \mathrm{L}^{-1} \mathrm{BAP}+0.5 \mathrm{mg} / \mathrm{L}^{-1} \mathrm{NAA}$ & - & - & - & + & - & - & - & + & $\mathrm{W}$ & Y & Y & $\mathrm{G}$ \\
\hline $0.5 \mathrm{mg} / \mathrm{L}^{-1} \mathrm{BAP}+0.5 \mathrm{mg} / \mathrm{L}^{-1} \mathrm{IAA}$ & - & - & - & + & - & - & + & + & W & $\mathrm{W}$ & $\mathrm{Y}$ & $\mathrm{G}$ \\
\hline
\end{tabular}

Notes: $\quad$ Root $(-=$ root nodular, $+=$ root formed); shoot $(-=$ shoot nodular, $+=1$ pair leaves, $++=>1$ pair leaves $)$; $\mathrm{W}=$ white, $\mathrm{Y}=$ yellowish, $\mathrm{G}=$ greenish, $\mathrm{YG}=$ yellowish green. 
Likewise, addition of PGRs also effected in rooting development. Addition of $0.5 \mathrm{mg} . \mathrm{L}^{-1}$ NAA resulted in the most extensive root than the others. While addition of $0.5 \mathrm{mg} \cdot \mathrm{L}^{-1} \mathrm{BAP}$ resulted in the shortest root's length than other treatments. Auxin and cytokinin have an opposite function in the root meristem. Auxin promoted development of root meristems. Adding exogenous auxin increased root size, while adding cytokinins inhibited root growth (Chapman \& Estelle, 2009). Hasanah \& Setiari (2007) mentioned that the use of auxin in Pogostemon cablin had an optimal effect on the number of roots and root's length. This indicated that auxin triggers root initiation and promotes root elongation.

\section{Germinating Embryo Weight}

Besides affected on size of the embryo, supplemented of PGRs also affected on C. liberica germination embryo weight. Addition $0.5 \mathrm{mg} . \mathrm{L}^{-1}$ BAP produced the highest dry weight of germinating embryo. Whereas
MS medium with addition of auxin individually resulted in the lowest of dry weight of germinating embryo (Table 6).

The data showed that after 12 weeks of culture, germination of embryo of $C$. liberica had highest dry weight on MS medium containing $0.5 \mathrm{mg} . \mathrm{L}^{-1} \mathrm{BAP}(1.86 \mathrm{mg})$. Increasing of dry weight in the embryo somatic with the addition of BAP also occurs in different plants. Zubo et al. (2008) mentioned that cytokinins increased the number of carbon sequestration to the function of photosynthesis. In addition, cytokinins on media culture also stimulated transcription process in barley plants. In other plants, application of $5 \mathrm{mg} . \mathrm{L}^{-1}$ BAP was sufficient to increase dry weight of Epipremnum aureum L. compared with control. This study also pointed out that addition of BAP increase relative growth rate (RGR) (Benedetto et al., 2015). Application of BAP in the medium resulted in significantly different of dry weight compared with application of auxins and cytokinins separately or in combination.

Table 5. The effect of auxin and cytokinin in MS medium on the size of germinating embryo of $C$. liberica at $12^{\text {th }}$ weeks after culture

\begin{tabular}{lcc}
\hline Medium culture & Shoot length $(\mathrm{mm})$ & Root length $(\mathrm{mm})$ \\
\hline $0.5 \mathrm{mg} \cdot \mathrm{L}^{-1} \mathrm{BAP}$ & $5.20 \pm 0.17^{\mathrm{d}}$ & $0.81 \pm 0.18^{\mathrm{a}}$ \\
$0.5 \mathrm{mg} \cdot \mathrm{L}^{-1}$ IAA & $4.00 \pm 0.35^{\mathrm{c}}$ & $1.11 \pm 0.23^{\mathrm{b}}$ \\
$0.5 \mathrm{mg} . \mathrm{L}^{-1} \mathrm{NAA}$ & $2.98 \pm 0.20^{\mathrm{a}}$ & $3.13 \pm 0.29^{\mathrm{e}}$ \\
$0.5 \mathrm{mg} . \mathrm{L}^{-1} \mathrm{BAP}+0.5 \mathrm{mg} \cdot \mathrm{L}^{-1} \mathrm{NAA}$ & $3.22 \pm 0.09^{\mathrm{b}}$ & $2.12 \pm 0.19^{\mathrm{d}}$ \\
$0.5 \mathrm{mg} \cdot \mathrm{L}^{-1}$ BAP $+0.5 \mathrm{mg} \cdot \mathrm{L}^{-1} \mathrm{IAA}$ & $5.02 \pm 0.20^{\mathrm{d}}$ & $1.32 \pm 0.16^{\mathrm{c}}$
\end{tabular}

Note: $\quad$ Means followed by the same letters are not significantly different from each other at $\mathrm{P}<0.05$ determined by Duncan's multiple range test (DMRT).

Table 6. The effect of adding auxin and cytokinin in MS medium on the weight of germinating embryo of $C$. liberica at $12^{\text {th }}$ weeks after culture

\begin{tabular}{lcc}
\hline Medium culture & Fresh weight $(\mathrm{mg})$ & Dry weight $(\mathrm{mg})$ \\
\hline $0.5 \mathrm{mg} \cdot \mathrm{L}^{-1} \mathrm{BAP}$ & $14.94 \pm 0.45^{\mathrm{d}}$ & $1.86 \pm 0.055^{\mathrm{d}}$ \\
$0.5 \mathrm{mg} \cdot \mathrm{L}^{-1}$ IAA & $5.05 \pm 0.36^{\mathrm{a}}$ & $0.631 \pm 0.044^{\mathrm{a}}$ \\
$0.5 \mathrm{mg} . \mathrm{L}^{-1} \mathrm{NAA}$ & $5.09 \pm 0.42^{\mathrm{a}}$ & $0.636 \pm 0.052^{\mathrm{a}}$ \\
$0.5 \mathrm{mg} . \mathrm{L}^{-1} \mathrm{BAP}+0.5 \mathrm{mg} / \mathrm{L}^{-1} \mathrm{NAA}$ & $7.06 \pm 0.48^{\mathrm{b}}$ & $0.882 \pm 0.059^{\mathrm{b}}$ \\
$0.5 \mathrm{mg} \cdot \mathrm{L}^{-1} \mathrm{BAP}+0.5 \mathrm{mg} / \mathrm{L}^{-1} \mathrm{IAA}$ & $12.30 \pm 0.47^{\mathrm{c}}$ & $1.537 \pm 0.058^{\mathrm{c}}$ \\
\hline
\end{tabular}

Note: $\quad$ Means followed by the same letters are not significantly different from each other at $(\mathrm{p}<0.05)$ determined by Duncan's multiple range test. 


\section{CONCLUSIONS}

Application of auxin and cytokinin on development stage affected quality and weight of somatic embryos. Auxin and cytokinin require a different concentration to obtain an optimal somatic embryo and germination embryo. In the development stage, precise compositions of auxin and cytokinin are needed to support somatic embryos. Somatic embryos on MS medium containing $1 \mathrm{mg} . \mathrm{L}^{-1}$ BAP without 2,4-D produced somatic embryo C. liberica with an optimal quality as well as heaviest somatic embryos. Whilst, auxins and cytokinins also influenced the quality and weight of geminating embryos of $C$. liberica on gemination stage. $C$. liberica germinating embryo growth optimally on MS medium supplemented with BAP individually or MS medium with $0.5 \mathrm{mg} \cdot \mathrm{L}^{-1} \mathrm{BAP}$ combining with $0.5 \mathrm{mg} . \mathrm{L}^{-1}$ IAA for shooting development. Whereas on rooting development, addition of $0.5 \mathrm{mg} . \mathrm{L}^{-1} \mathrm{NAA}$ in $\mathrm{MS}$ medium culture produced optimal germinating embryos. Moreover, germinating embryo of $C$. liberica on MS medium containing $0.5 \mathrm{mg} . \mathrm{L}^{-1} \mathrm{BAP}$ had a highest dry weight.

\section{ACKNOWLEDGEMENTS}

The authors thank to Airlangga University that supported this research by internal research grant.

\section{REFERENCES}

Aga, E. \& Y. Khillare (2017). In vitro multiplication of Coffea arabica, L. from leaf explant through indirect somatic embryogenesis. International Journal of Botany Studies, 2(1), 17-22.

Ahmed, W.; T. Feyissa \& T. Disasa (2013). Somatic embryogenesis of a coffee (Coffea arabica L.) hybrid using leaf explants. Journal of Horticultural Science \& Biotechnology, 88(4), 469-475.
Ali, S. \& B. Mirza (2006). Micropropagation of rough lemon (Citrus jambhiri Lush): Effect of explants type and hormone concentration. Acta Botanica Croatica, 65, 137-146.

Ardiyani, F. (2015). Morphological characterization and identification of Coffea liberica callus of somatic embryogenesis propagation. Pelita Perkebunan, 31, 81-89.

Ashihara, H. \& A. Crozier (2001). Caffeine: a well known but little mentioned compound in plant science. Trends Plant Science, 6, 407-4.

Benedetto, D.; C. Galmarini \& J. Tognetti (2015). Exogenous cytokinin promotes Epipremnum aureum L. growth through enhanced dry weight assimilation rather than through changes in partitioning. American Journal of Experimental Agriculture, 5, 419-434.

Berthouly, M. \& N.M. Michaux-Ferriere (1996). High frequency somatic embryogenesis in Coffea canephora. Plant Cell, Tissue and Organ Culture, 44, 169-176.

Chapman, E.J. \& M. Estelle (2009). Cytokinin and auxin intersection in root meristem. Genome Biology, 10(210), 1-2.

Cybularz-Urban, T.; E. Hanus-Fajerska \& A. Swiderski (2007). Preliminary morphological, anatomical and biochemical characteristic of micropropagated Cattleya under UV-A and white light illumination. Zeszyty Problemowe Postepow Nauk Rolniczych, 523, 59-67.

Devendra, B.N.; V.S.S.L.P. Talluri \& N. Srinivas (2012). Callus induction and somatic embryogenesis of Moringa oleifera Lam an anti-radiation plant. Journal of Agricultural Technology, 8, 1953-1963.

Etienne H.; E. Dechamp; D. Barry-Etienne \& B. Bertrand (2006). Bioreactors in coffee micropropagation. Brazilian Journal of Plant Physiology, 18, 45-54.

Fereol, L.; V. Chovelon; S. Causse; N. MichauxFerriere \& R. Kahane (2002). Evidence 
of a somatic embryogenesis process for plant regeneration in garlic (Allium sativum L.). Plant Cell Reports, 21, 197-203.

Guan, Y.; S.G. Li; X.F. Fan \& Z.H. Su (2016). Application of somatic embryogenesis in woody plants. Frontiers in Plant Science, 7, 1-12.

Hasanah, F.N. \& N. Setiari (2007). Pembentukan akar pada stek batang nilam (Pogostemon cablin Benth.) setelah direndam IBA (Indol Butyric Acid) pada konsentrasi berbeda. Buletin Anatomi dan Fisiologi, $17,1-6$.

Hua-Su, Y.; Y.B. Liu \& X.S. Zhang (2011). Auxincytokinin interaction regulates meristem development. Molecular Plant, 4, 616-625.

Isah, T. (2016). Induction of somatic embryogenesis in woody plants. Acta Physiologiae Plantarum, 38, 1-22.

Kaviani, B. (2013). Somatic embryogenesis and plant regeneration from embryonic axes and cotyledons explants of tea (Camellia sinenis L.). Journal of Ornamental Plants, 3, 33-38.

Kazmi, S.K.; S. Khan; N. Kabir; A.A. Mirbahar; M. Raziq \& N. Kauser (2015). Embryogenic callus induction, somatic embryogenesis, regeneration and histological studies of Kinnow Mandarin (Citrus Reticulata Blanco L.) from nucellar embryo and epicotyl region. Pakistan Journal of Botany, 47(1), 305-310.

Konan, K.E.; T.D. Gasselin; Y.J. Kouadio; A. Flori, A. Rival; Y. Duval \& C. Pannetier (2010). In vitro conservation of oil palm somatic embryos for 20 years on a hormonefree culture medium: characteristics of the embryogenic cultures, derived plantlets and adult palms. Plant Cell Reports, 29, 1-13.

Lopes, C.R. \& L.C. Monaco (1979). Chemotaxonomic studies of some species of the genus Coffea. Journal of Plant Crops, 7, 6-14.
Muniswamy, B.; B. Kosaraju; M.K. Mishra \& R. Yenugula (2017). Field performance and genetic fidelity of micropropagated plants of Coffea canephora (Pierre ex A. Froehner). Open Life Sciences, 12, 1-11.

Nakamura, T.; T. Taniguchi \& E. Maeda (1992). Studies on somatic embryogenesis of coffee by scanning electron microscopy. Japan Journal of Crop Science, $61,477-481$.

N'Diaye, A.; V. Poncet \& J. Louarn (2005). Genetic differentiation between Coffea liberica var. liberica and $C$. liberica var. dewevrei and comparison with $C$. canephora. Plant Systematics and Evolution, 253, 95-104.

Nolan, K.E. \& R.J. Rose (1998). Plant regeneration from cultured Medicago truncatula with particular reference to abscisic acid and light treatments. Australian Journal of Botany, 46, 151-160.

Ogata, Y.; M. Lizuka; D. Nakayama; M. Ikeda; H. Kamada \& T. Koshiba (2005). Possible involvement of abscissic acid in the induction of secondary somatic embryogenesis on seed coat-derived carrot somatic embryos. Planta, 22, 417-423.

Raghavan, V. (2004). Role of 2,4-dichlorophenoxyacetic acid (2,4-D) in somatic embryogenesis on cultured zygotic embryos of Arabidopsis: cell expansion, cell cycling, and morphogenesis during continuous exposure of embryos to 2,4-D. American Journal of Botany, 91, 1743-1756.

Santana-Buzzy, N.; R. Rojas-Herrera; R.M. GalazÁvalos; J.R. Ku-Cauich; J. MijangosCortés, L.C. Gutiérrez-Pacheco (2007). Advances in coûee tissue culture and its practical applications. In Vitro Cellular \& Developmental Biology, 43, 507-520.

Sridevi, V. \& P. Giridhar (2014). In vitro shoot growth, direct organogenesis and somatic embryogenesis promoted by silver nitrate in Coffea dewevrei. Journal 
of Plant Biochemistry and Biotechnology, 23, 112-118.

Vondráková, Z.; K. Eliášová; L. Fischerová \& M. Vágner (2011). The role of auxins in somatic embryogenesis of Abies alba. Central European Journal of Biology. 6, 587-596.

Wardatutthoyyibah; R.S. Wulandari \& H. Darwati (2015). Penambahan auksin dan sitokinin terhadap pertumbuhan tunas dan akar gaharu (Aquilaria malaccensis Lamk) secara in vitro. Jurnal Hutan Lestari, 3, 43-50.

Widiastoety, D. (2014). Pengaruh auksin dan sitokinin terhadap pertumbuhan planlet anggrek Mokara Jurnal Hortikultura, 24, 230-238.
Wintgens, J.N. (2004). The Coffee Plant. p. 3-25. In: Coffee: Growing, Processing, Sustainable Production. Jean Nicolas Wintgens (eds.). Wiley-VCH Verlag GmbH \& Co. KGaA, Weinheim.

Yang, X. \& X. Zhang (2010). Regulation of somatic embryogenesis in higher plants. Critical Reviews in Plant Sciences, 29, 36-57.

Zubo, Y.O.; M.V. Yamburenko; S.Y. Selivankina; F.M. Shakirova; A.M. Avalbaev; N.Z. Kudryakova; N.K. Zubkova; K. Liere; O.N. Kulaeva; V.V. Kusnetsov \& T. Börner (2008). Cytokinin stimulates chloroplast transcription in detached barley leaves. Plant Physiology, 148, 1082-1093.

$$
* * 0 * *
$$

